\title{
Value, Transvaluation and Globalization ${ }^{1}$
}

\section{Steffen Dalsgaard}

IT University of Copenhagen

\section{Ton Otto}

\author{
Institution (Aarhus University and James Cook University)
}

$\mathrm{V}$

alue has been a central concept in anthropology and sociology since the birth of these disciplines (e.g. Marx, Simmel, Weber). In recent decades the concept has seen a revival (e.g. Graeber 2001; Eiss and Pedersen 2002; Pedersen 2008; Otto and Willerslev 2013), but while it has been debated and discussed, assessed and evaluated extensively, there are nonetheless still many things to be said about it. This volume addresses a particular perspective on value through the lens of 'transvaluation', and how transvaluation may denote a process that occurs in our current world system as an intrinsic effect of contemporary globalization.

Transvaluation - or umwertung aller Werte - originally stems from the works of Friedrich Nietzsche - especially Twilight of the Idols (1998[1889]) and The Anti-Christ (1969[1895]). Value here refers not to price or economic valuation, but to the ascription of meaning to the world, or to life or vitality as Nietzsche had it. Transvaluation was thus Nietzsche's assertion of the need to abandon and redefine the dominant values of his day, which he argued celebrated weakness instead of vitality. These values were typically associated with Christian notions of sin and guilt as suppressing the 'will to power' (in The Anti-Christ), transforming weakness into moral strength. But his work was also a reaction against what he called 'decadence' springing from the history of philosophy and especially Plato (in Twilight of the Idols). The weak (the collective) had in Nietzsche's perspective come to dominate the strong (the individual), who had become subject to a restraint of desire (through asceticism, sin and guilt), and suppression of vitality. Through altruism and pity, what used to be the natural order of life had become subverted to the dominance of the weak over the strong. Thus, in other words, socially and culturally stronger and more wilful persons were eventually dominated through collective norms. Since a person's earthly life in Christianity came to be the preparation for what happened after death, life itself lost meaning, and death (or the afterlife) came to dominate over the present (life).

\footnotetext{
${ }^{1}$ The articles in this special issue stem from the workshop 'Values of Dominance and Difference' held at The Cairns Institute, James Cook University (Australia), August 2012. The workshop was organized by the authors of this editorial along with Bruce Kapferer, Bergen, and it was funded by The Cairns Institute, the Transoceanik International Associated Laboratory (France and Australia), Bergen University (Norway), The Domestic Moral Economy Project (The UK and Australia), Aarhus University and the Danish Council of Independent Research (Denmark). We are furthermore grateful for the editorial help provided by Stephen Torre and for the advice of the anonymous reviewers.
} 
In this way the notion of transvaluation pointed to a reversal of what was considered the 'natural order' of weak and strong, and good and bad, and not least how values are embedded both in personal desire but also in individual action (to value something is a form of action). In addition, Nietzsche points to how values entail a form of dominance. He introduces (in The Anti-Christ) the will to power, which is also the will to ascribe meaning to the world, to take responsibility for valuing the world and not just accept other people's values.

Nietzsche's perspective in many ways espoused both relativism and an anarchist form of individualism. An emphasis on independence and self-reliance endorsed the opportunity for strong individuals to succeed without having to hold back due to social and religious norms, which Nietzsche saw as 'illusions'. As such, Nietzsche's argument somewhat paradoxically mirrored the individualist tendencies developing in what were the contemporary variants of Christianity, where also piety (rather than pity) and the hard work of individuals came to articulate central values of what became known as capitalism (Weber 2003).

Nietzsche's work in general has inspired a large number of thinkers of the $20^{\text {th }}$ Century and today it is particularly present through the popularity of poststructuralist philosophy (e.g. Michel Foucault, Gilles Deleuze). Nietzsche's notion of power, his individualist relativism, and the focus on 'becoming' rather than fixity (e.g. Nietzsche 1977: 197), should be recognizable to many scholars especially in anthropology. The concept of transvaluation however - has not received the same kind of attention. For example, in anthropology the notion has been used briefly, a bit differently and sometimes without direct reference to Nietzsche himself (Tambiah 1996; Hastrup 2006). In David Graeber's work, which is today much cited when it comes to debates about value, there is only a fleeting inspiration, where he discusses the poststructuralist theorization of value that depends on a notion of 'desire' as "the fundamental constituent of all reality" (2001: 258). Likewise in an essay by Paul Eiss and David Pedersen there is only a brief mention of Michael Hardt's and Antonio Negri's definition 'of "transvaluation" to refer to a "capacity not only to destroy the values that descend from the transcendental realm of measure but also to create new values"' (Hardt and Negri 2000: 359, cited in Eiss and Pedersen 2002: 286).

We want to argue that transvaluation as a process related to domination and to reversals of a moral order is inherently at stake, when different value systems are brought into alignment or conflict through processes such as globalization, modernization, marketization, development and so on. We live in a world where different values are constantly contrasted and where negotiations of value differences are daily occurrences to many people even if only tacitly so. A term like 'hybridity' has gained popularity probably for this reason (see Nederveen Pieterse 2009). At the same time, coherent value systems are seen as becoming more difficult to sustain with the result that individuals, who can be flexible and navigate between different cultural and social norms are valued. To be sure, there are many potential outcomes to the clashes of value: domination, submission, domestication etc., and value can be particular difficult to disentangle from power. Nietzsche spoke of power not in the sense of domination over others but in the sense of the will of the person to be independent (de Huszar 1945), but to be sure one person's independence may lead to the domination of one set of values over those of others - or at least their conflict. At the same time, in Nietzsche's critique one sees that exploitation and competition are valued as 'natural' and as the means to elevate individuals. 
Today, if one accepts that individualist capitalism - even if it was not perceived by Nietzsche to be the opposite of the life-denying values of Christianity as such - has succeeded in becoming the dominant form of value-generating process under contemporary globalization, then the transvaluation back to 'natural' values desired by Nietzsche has in some respects taken place. People in the secular western world have to a large extent rejected Christian moral domination, yet not as the result of an individualist creation of independent value, but paradoxically as a faith in a new system where what Nietzsche valued (the independent individual) has become the new social norm. The market, and the possessive individualism espoused by it (Macpherson 1962), has come to dominate multiple social and cultural spheres including the environment, art, religion and even the body. Notions of competition and the constant pursuit of success in this life rather than the afterlife, dominate not only consumers' choices in the marketplace but also increasingly the content of moral and personal values (what one wants to do with one's life whether at work or in the domestic sphere). In Max Weber's view (2003[1922]), capitalism began exactly as an alignment of individuals' orientation towards the afterlife with the accumulation of monetary wealth that previously had led to moral and religious condemnation to either Hell or Purgatory (e.g. Le Goff 1990), whereas contemporary capitalism has entailed that the self-fulfilment of the person as an entity is to be completed in the here and now - including bodily as would be the case with transgendered persons (cf. Fortier this volume). The person itself is in this regime of value an entity to be constantly improved and optimized through both social and technological means - an entity that has no boundaries and is never complete even if this completeness is merely what one seeks to achieve but can never reach. The 'dysfunctional' person is in this view a person, who has given up trying to attain improvement (Garond this volume).

If one follows Nietzsche all the way, capitalist individualism is of course another value illusion that any individual would have to go beyond in order to accept the relativity of perspective. For instance Michael Hardt and Antonio Negri (2000) have in this regard referred to the rise of social movements in resistance to capitalism and the markets as a form of transvaluation. Although Hardt and Negri echo Nietzsche by taking their starting point in the creative ability of individuals to make social structures, they fail to recognise how the individual is mirrored in the Other (cp. Kapferer 2002). We will thus argue that contemporary capitalism as a process of transvaluation may appear on the surface to be what Nietzsche had in mind, but in reality probably is far from it, exactly because of his emphasis on the role of the individual rather than the social (but see Siemens 2002), and because of capitalism's ability, when encountering critique or resistance, to be successful in taking it in and mutating into new forms of social and normative structure (Boltanski and Chiapello 2005; Thrift 2005). In debates about cultural globalisation related processes have been touched upon in terms of ‘hybridisation' (Nederveen Pieterse 2009).

We do suggest, however, that the concept of transvaluation, because of its origin and historical pairing of individualism and value creation, may give new insights and be an interesting overarching model or metaphor for the reactions to the ability of the market to successfully displace value systems locally and globally, individually as well as socially. The contributions to this collection all address ways, in which domination and difference in value are entangled and come into conflict. The cases concern such different 'sites' as categorisations of people as dysfunctional, work values and choices for jobs, the institutionalization of gender neutrality or transgender categories, heritage reappropriation, the collection of differently designed cultural artefacts and the market in Aboriginal art. The first three articles relate to the struggles of value embracing the individual in relation to dominant social norms. The last three articles address clashes with the values of the market in particular that of traditional art and heritage. 
Lise Garond eloquently discusses the complexity of mainstream and especially neoliberal Australia's relationship to Aboriginals through the label 'dysfunctional', which is applied equally to communities and individuals. With the infamous Palm Island case, Garond shows the contradictory content of statements about Aboriginal communities, and most importantly how they are characterized by what they 'lack' - a white, neoliberal sense of private property and an almost Nietzschean desire for individuals to realize themselves as 'responsible' and independent individuals - even if this desire is an institutionalized norm rather than a personal will. Nietzsche would most likely not have agreed to the neoliberal dogmas, but this attempt of dominance must be taken seriously as an ongoing threat to Palm Islanders' right to be 'different'. Conversely Garond's contribution displays the need for a transvaluation of the one-sided image presented of Palm Island in mainstream media.

As a contrast to the dysfunctional, working individuals' choice of and satisfaction with their job is motivated by many factors - not least what has become known in organizational research as 'work values'. Josephine Pryce's contribution reviews a long series of approaches to the question of how and why people value their work individually and socially, and she analyses a case of conflicting values between management and employees within the hospitality industry. Work values can of course not be completely separated from what guides people in the context of the rest of their lives, and workplaces may benefit from paying attention to employees' values, but certainly also to how complementary, or conversely conflicting, work values are hierarchically ordered or differentiated. Pryce suggests a number of themes that workplace studies would benefit from, and one could add that much closer attention to the processes of transvaluation between work and non-work spheres of life should be among them.

Corinne Fortier investigates the predicaments felt by trans- and intersex people, and how they struggle against what they experience as the domination of mainstream gender binaries. The body has long been recognized as a site of contestation over moral values and the right to define the most basic physical conditions of one's own existence (the physical body and how it meets and is met by the world). In Nietzsche's optic, trans- and intersex people stand out as truly will-full makers of their own categories, values and selves in spite of stigmatization and difficulties with personally reconciling dominant with individual variant values.

Jessica De Largy Healy and Barbara Glowczewski present an overview of some of the current debates relating to understandings of heritage and its appropriation. Heritage encapsulates not only knowledge but also politics and ethics. Cultural and traditional practices are objects of value not only through their reification as art, ritual or performance, but also in new ways engendered by the digitisation of communication. The Google Corporation can for example be seen as engaged in an enterprise of making knowledge in all its forms free and open to the world, but at the same time this dispossess numerous indigenous people, even if YouTube (owned by Google) has become a favourite channel for sharing and disseminating tradition and thus is regarded by some as their agent for transvaluation.

The contribution by Aaberge, Barnard, Greer and Henry shows how Aboriginal objects from Northern Queensland have long been prized collectors' items but also - of course - valuable in multiple ways to the communities, where they were made. The shields and baskets in question have long been interwoven in global networks of valuation depending on such widely different forms such as aesthetics, functionality, indigenous meaning as well as market price. Today these objects are nonetheless important temporal connectors of past and 
present to contemporary Aboriginal artists. They both serve as sources of inspiration and as indicators of direct relationships, when DNA from the material of the old objects can be checked with contemporary descendants. The use of bodily material in the making of these pieces, which have served functional as well as symbolic purposes, does lead to potential clashes of valuation between market and tradition, and raises important moral questions of ownership.

The final contribution by Geraldine Le Roux discusses the complex entanglement of values in the production and marketing of Australian Aboriginal art. This multimillion-dollar industry has to balance market price, indigenous values and fair trade ethics enforced by the state. Noteworthy is for example the contrast between the practice of 'carpetbaggers' motivated by market price and demand, and indigenous sociocultural values embedded in the art but also in the stories it communicates. This is emphasised with reference to a move from creation and the valuation of the creative act itself among Aboriginal communities to the imposition of norms of quick and effective production or reproduction for the market. Having been removed from local stories, the artwork is sold alienated from the artist but nevertheless with a combination of old and new stories attached to stress unique and sometimes exoticised authenticity. While indigenous agency is often denied in the stories accompanying a piece of art in the market, the Aboriginal artists are themselves aware of the exploitation, and they sometimes may produce - in their own view - poor quality work as form of resistance in the face of dominance.

\section{Works Cited}

Boltanski, L. and E. Chiapello 2005. The New Spirit of Capitalism. London: Verso.

Eiss, P. and D. Pedersen (eds.) 2002. Values of Value. Special issue of Cultural Anthropology 17,3 .

Graeber, D. 2001. Toward an Anthropological Theory of Value. New York: Palgrave.

Hardt, M. and A. Negri 2000. Empire. Cambridge, Mass.: Harvard University Press

Hastrup, K. 2006. Closing Ranks. The Australian Journal of Anthropology 17(2): 147-160.

de Huszar, G. 1945. Nietzsche's Theory of Decadence and the Transvaluation of All Values. Journal of the History of Ideas 6, 3: 259-72.

Kapferer, B. 2002. Foundation and Empire (with Apologies to Isaac Asimov): A Consideration of Hardt and Negri's Empire. Social Analysis 46, 1: 167-179.

Le Goff, J. 1992. Your Money or Your Life. New York: Zone Books.

MacPherson, C.B. 1962. The Political Theory of Possessive Individualism. Oxford: Clarendon.

Nederveen Pieterse, J. 2009. Globalization and Culture. $2^{\text {nd }}$ Edition. New York: Rowman \& Littlefield Publishers.

Nietzsche, F. 1969 [1895]. The Anti-Christ. Harmondsworth: Penguin Books. 
Nietzsche, F. 1977. A Nietzsche Reader. (Selected and Translated by R. J. Hollingdale). London: Penguin Classics.

Nietzsche, F. 1998 [1889]. Twilight of the Idols. (Transl. by D. Large). Oxford: Oxford University Press.

Otto, T. and R. Willerslev (eds.) 2013. Value as Theory. Special double issue of Hau: Journal of Ethnographic Theory 3, 1-2.

Pedersen, D. (ed.) 2008. Toward a Value Theory of Anthropology. Special issue of Anthropological Theory 8, 1.

Siemens, H.W. 2002. Agonal Communities of Taste. Journal of Nietzsche Studies 24: 83-112.

Tambiah, S. 1996. Leveling Crowds. Berkeley: University of California Press.

Thrift, N. 2005. Knowing Capitalism. London: Sage.

Weber, M. 2003 [1922]. The Protestant Ethic and the Spirit of Capitalism. Mineola, NY: Dover Publications. 